Original Article

\title{
Herbivory and leaf expansion of Cyathea phalerata Mart. (Cyatheaceae) in subtropical Atlantic Forest, southern Brazil
}

\author{
Herbivoria e expansão foliar de Cyathea phalerata Mart. (Cyatheaceae) em Floresta \\ Atlântica subtropical no sul do Brasil
}

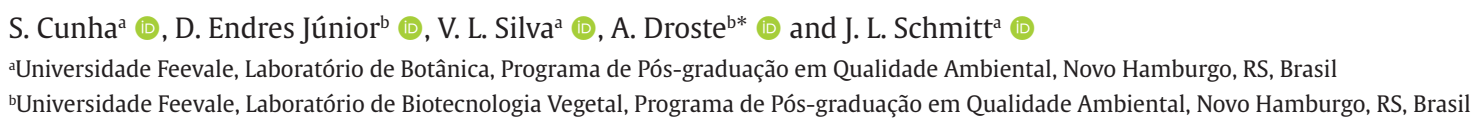

\begin{abstract}
Herbivory is an interaction with great impact on plant communities since relationships between herbivores and plants are fundamental to the distribution and abundance of species over time and space. The aim of this study was to monitor the rate of leaf expansion in the tree fern Cyathea phalerata and evaluate the damage caused by herbivores to leaves of different ages and whether such damage is related to temperature and precipitation. The study was performed in a subtropical Atlantic Forest fragment located in the municipality of Caraá, in the northeast hillside of Rio Grande do Sul state, in southern Brazil. We monitored 24 mature individuals of $C$. phalerata with croziers in a population of approximately 50 plants. Leaf expansion rate, percentage of damaged leaves and leaf blade consumption rate by herbivory were calculated. Monthly means for temperature and accumulated rainfall were calculated from daily data. Croziers of $C$. phalerata were found to expand rapidly during the first and second months after emergence $\left(3.98 \mathrm{~cm}_{\text {day }}{ }^{-1} ; 2.91 \mathrm{~cm}\right.$ day $^{-1}$, respectively). Damage caused by herbivory was observed in all of the monitored leaves, but none of the plants experienced complete defoliation. The highest percentage (57\%) of damaged leaves was recorded at 60 days of monitoring, and also the highest monthly consumption rate of the blade (6.04\%) occurred with young, newly-expanded leaves, while this rate remained between 1.50 and $2.21 \%$ for mature leaves. Rates of monthly leaf consumption and damaged leaves showed positive and strong relationship with each other and with temperature. The rapid leaf expansion observed for $C$. phalerata can be considered a phenological strategy to reduce damage to young leaves by shortening the developmental period and accelerating the increase of defenses in mature leaves.
\end{abstract}

Keywords: climate, herbivore, leaf production, phenology, tree fern.

\begin{abstract}
Resumo
A herbivoria é uma interação de grande impacto sobre as comunidades de plantas, uma vez que as relações entre herbívoros e plantas são fundamentais para a distribuição e abundância das espécies ao longo do tempo e do espaço. O objetivo deste estudo foi monitorar a taxa de expansão foliar da samambaia arborescente Cyathea phalerata e avaliar o dano causado por herbívoros a folhas de diferentes idades, assim como verificar se este dano está relacionado à temperatura e à precipitação. 0 estudo foi realizado em um fragmento de Floresta Atlântica subtropical localizado no município de Caraá, na encosta nordeste do estado do Rio Grande do Sul, no sul do Brasil. Nós monitoramos 24 indivíduos maduros de $C$. phalerata com báculos em uma população de aproximadamente 50 plantas. A taxa de expansão foliar, a porcentagem de folhas danificadas e a taxa de consumo da lâmina foliar por herbivoria foram calculados. Médias mensais de temperatura e precipitação acumulada foram calculadas a partir de dados diários. Báculos de C. phalerata expandiram rapidamente durante o primeiro e o segundo mês após emergência ( $3,98 \mathrm{~cm} \mathrm{dia}^{-1} ; 2,91 \mathrm{~cm} \mathrm{dia}^{-1}$, respectivamente). $O$ dano causado por herbivoria foi observado em todas as folhas monitoradas, mas nenhuma das plantas sofreu desfolhação completa. A maior porcentagem (57\%) de folhas danificadas foi registrada aos 60 dias de monitoramento, e também a maior taxa de consumo mensal (6,04\%) ocorreu em folhas jovens, recém expandidas, enquanto esta taxa permaneceu entre 1,50 e 2,21\% em folhas maduras. As taxas mensais de consumo da lâmina foliar e de folhas danificadas mostraram relação positiva e forte entre si e com a temperatura. A rápida expansão foliar observada em C. phalerata pode ser considerada uma estratégia fenológica para reduzir o dano a folhas jovens, abreviando o período de desenvolvimento e acelerando o aumento das defesas em folhas maduras.
\end{abstract}

Palavras-chave: clima, herbívoro, produção foliar, fenologia, samambaia arborescente.

*e-mail: annette@feevale.br

Received: November 8, 2020 - Accepted: January 5, 2021 


\section{Introduction}

Herbivory is one the most negative impactful interactions in plant communities (Coley and Barone, 1996), since relationships between herbivores and plants are fundamental to the distribution and abundance of species over time and space (Edwards and Wratten, 1981). Plants respond in many ways to herbivory, such as regulating consumption by producing substances that change the concentrations of nutrients in tissues (Neuvonen and Haukioja, 1984; Tuomi et al., 1984; Agrawal, 2007; Futuyma and Agrawal, 2009); depositing a thicker cuticle, thickening the epidermis and producing and depositing abundant crystals in leaves; using physical barriers, such as trichomes and leaf fibers (Fernandes, 1994; Mello and Silva-Filho, 2002; Hanley et al., 2007); and employing chemical defenses, such as toxic substances, repellants or compounds that interfere with the digestibility of vegetal tissue (Mello and Silva-Filho, 2002). In addition to resistance strategies, some plants may develop other characteristics to reduce the impact of damage from herbivory, such as compensatory growth and reproductive rate (Strauss and Agrawal, 1999), and nectaries that promote ant visitation, reducing the damages by herbivores, once the ants protect the ferns against antagonistic insects (Koptur et al., 2013). Rates of herbivory in plant populations can vary according to climate seasonality (Nascimento et al., 2011), such as in some tropical forests where the abundance of herbivores is higher during the wet season following the period of leaf flush of many plant species (Lowman, 1982; Coley and Barone, 1996).

Morphological, physical and chemical defenses do not seem as effective at protecting young leaves as they are for mature leaves, with young leaves being damaged more for most species (Feeny, 1970; Coley, 1983; Coley and Aide, 1991; Aide, 1993). This discrepancy could be due to the greater nutritional content, and lower concentration and diversity of defense compounds of expanding young leaves (Crawley, 1983; Lowman, 1985). Ferns, however, present a different scenario. Despite the softer texture, higher water content and higher nutrient concentration of young fern leaves (Cherrett, 1972; Bowers and Porter, 1981; Crawley, 1983; Howard, 1987), which would likely increase feeding preferences for them, they possess toxic substances (Zangerl and Bazzaz, 1992). Thus, higher rates of herbivory on mature than young leaves have been recorded for terrestrial and epiphytic ferns (herbaceous species) (Mehltreter and Tolome, 2003; Mehltreter et al., 2006; Patra and Bera, 2007). Nonetheless, a still understudied strategy that may explain the preference for mature leaves of ferns is phenological defense. Employing such a defense, fern leaves can: (i) expand rapidly; (ii) be produced synchronously at community level to satiate herbivores; and/or (iii) be produced during seasons with low herbivore abundance (Aide, 1988, 1991, 1993; Murali and Sukumar, 1993).

Cyathea phalerata Mart. (Cyatheaceae) is one of the Brazilian ferns that possesses arborescent habit (Schmitt and Windisch, 2010, 2012; Mallmann et al., 2019), with a caudex that can reach up to 10 meters in height with leaves of up to 3.5 meters in length with thick blades, which may or may not have trichomes on the abaxial and adaxial surfaces (Fernandes, 2003). The species is widely distributed in Brazil, occurring in all regions (Windisch and Santiago, 2015), and also in Bolivia (Lehnert, 2006). Information on C. phalerata is still limited and practically restricted to taxonomy (Fernandes 2003), pharmacology (Hort et al., 2008), and germination and gametophyte development (Marcon et al., 2017). Due to the drastic reduction of the Atlantic Forest (SOS Mata Atlântica, 2020), and having only been registered between latitudes $29^{\circ} 17^{\prime}-31^{\circ} 00^{\prime} \mathrm{S}$ (Gonzatti et al., 2016), C. phalerata is considered Critically Endangered by the list of endangered species of flora of the state of Rio Grande do Sul (Rio Grande do Sul, 2014).

The authors observed frequent and intense damage to leaves at the beginning of a phenological study of C. phalerata in a subtropical climate in southern Brazil. The lifespan of the leaves of C. phalerata exceeds one year, as in most species of the genus (mean of 17.3 months according to the survey done by Silva et al., 2018). This allows herbivory monitoring on the same leaves throughout all seasons of the year. Considering that herbivores act on vegetative growth (Crawley, 1989), and that they could harm leaf growth and development of ferns with different intensities according to the climate (Patra and Bera, 2007) and the stage of leaf development (Mehltreter and Tolome, 2003; Mehltreter et al., 2006), this study aimed to monitor $C$. phalerata plants for leaf expansion and consumption by herbivores and to assess whether they are related to temperature and precipitation. In situ monitoring was developed to address the following hypotheses: (1) herbivory rates will be higher for mature leaves than for young leaves; and (2) damage intensity will be related to temperature but not to precipitation, since rainfall is well-distributed throughout the year in the studied region.

\section{Material and Methods}

\subsection{Study area}

The study was performed in a subtropical Atlantic Forest fragment located in the municipality of Caraá, in the northeast hillside of Rio Grande do Sul state (RS) in southern Brazil. The studied population of $C$. phalerata is located in a one-hectare plot (29² $42^{\prime} 25.0^{\prime \prime}$ S, 50¹7'27.8” W; 420 m asl). According to the Köppen climate classification, the region has a humid subtropical climate (Cfa) characterized by well-distributed rainfall throughout the year (Peel et al., 2007).

\subsection{Leaf expansion, leaf damage and leaf blade consumption rates}

We selected for monitoring 24 mature individuals of C. phalerata (evidenced by the production of spores), in a wild population with approximately 50 plants on September 2014 (Time 0). The plants were selected because they possessed croziers at the time of the start of the study. Two leaves in expansion were selected in each plant and marked with rubber rings. Leaf length was measured monthly, from October 2014 to September 2015, using a 
measuring tape. Leaf expansion rate, expressed as $\mathrm{cm}_{\text {day }}{ }^{-1}$, was determined by dividing the length of each totally expanded leaf by the total number of days since crozier production. Each of the 48 marked leaves was inspected during monthly field work.

Due to the large size of the leaves, herbivory was estimated visually in situ for each leaf and assigned to one of six classes of leaf area consumption denoting the proportion of leaf area lost: $0,1-10,11-25,26-50,51-75$ and $76-100 \%$, according to the method of Winkler et al. (2005) already applied to other ferns. The class median (e.g. the median of the $1-10 \%$ class is 5.5 ) for each leaf was used to calculate the mean consumption rate per leaf (Mehltreter and Tolome, 2003).

The monthly consumption rate (MC) was calculated for each leaf blade by the formula: $\mathrm{MC}=\mathrm{C} 2-\mathrm{C} 1$, where $\mathrm{C} 2$ = leaf area consumed in a given month and $\mathrm{C} 1$ = leaf area consumed in the previous month. The cumulative consumption rate $(\mathrm{AC})$ was calculated for each leaf blade by the formula: $\mathrm{AC}=\mathrm{MC} 1+\mathrm{MC} 2+\mathrm{MC} 3+\ldots+\mathrm{MC}$, were $\mathrm{MC} 1$ is the consumption rate in November 2014, and so on, until September 2015.

\subsection{Meteorological data}

Data of temperature $\left({ }^{\circ} \mathrm{C}\right)$ and local precipitation $(\mathrm{mm})$ were obtained for October 2014 to September 2015 using a mobile meteorological station (Davis Vantage PRO 2 USB NS), which was located $7.5 \mathrm{~km}$ in straight-line distance from the site of the monitored plants $\left(29^{\circ} 44^{\prime} 15.88^{\prime \prime} \mathrm{S}\right.$; $50^{\circ} 21^{\prime} 34.52$ " W; $375 \mathrm{~m}$ asl). Monthly means for temperature and accumulated rainfall were calculated from daily data.

\subsection{Statistical analysis}

Monthly consumption rates of leaf blades were not normally distributed (Shapiro-Wilk test), and so the Friedman test was applied followed by the Wilcoxon test with step (Holm, 1979) correction. The Spearman rank correlation test was used to assess the relationships between monthly consumption rate, number of damaged leaves, temperature and precipitation. To qualify the correlations, the following reference values were adopted (Callegari-Jacques, 2003): $0<\mathrm{r}<0.3$ (low), $0.3 \leq \mathrm{r}<0.6$ (moderate), and $r \geq 0.6$ (strong). Analyses were performed using SPSS version 25 , with a significance level of $5 \%$.

\section{Results}

Leaves of $C$. phalerata exhibited a faster expansion rate during the first and second months after their appearance $\left(3.98 \pm 1.69 \mathrm{~cm} \mathrm{day}^{-1} ; 2.91 \pm 1.89 \mathrm{~cm} \mathrm{day}^{-1}\right.$ in October and November 2014, respectively), when the monthly mean temperature was 19.5 and $20.9{ }^{\circ} \mathrm{C}$ (Figure 1). The maximum expansion rate of $7.16 \mathrm{~cm}$ day $^{-1}$ was registered in October. The final length of the expanded leaves was $174.27 \pm 50.38 \mathrm{~cm}$ with a range of $66-274 \mathrm{~cm}$.

The highest percentage of damaged leaves occurred with 60 days monitoring (Figure $2 \mathrm{~A}$ ), which was recorded in December 2014, when 57.1\% of the leaves showed new damage compared to the previous month. Comparing with other seasons, higher percentages of damaged leaves were observed late spring and summer, when leaves were in expansion and young (November 2014 to March 2015), and temperature varied from 20.9 to $23.6{ }^{\circ} \mathrm{C}$ (Figure 1). Herbivory was not observed in August and September 2015, respectively, in 300 and 330 days of monitoring (Figure 2A), after the coldest months (June and July). Positive and strong relationship was observed between the percentage of monthly damaged leaves and temperature ( $r s=0.657 ; \mathrm{p}=0.020$ ).

Leaf blade consumption was observed for all of the monitored leaves, but none of the plants experienced complete defoliation. A total of $27 \%$ (13) of the marked leaves died during the study period, three of which already had $50 \%$ of the blade consumed at 90 days. The 35 leaves that completed expansion by the end of the study period (September 2015) had a mean of cumulative consumption rate of $24.3 \%$ (Figure 2B). Most leaves had low to medium leaf consumption, with the lowest being $5.5 \%$, and the highest being $63 \%$ (according to respective class medians); most leaves had $11-25 \%$ and $26-50 \%$ of their blade consumed (Figure 2C).

The highest monthly consumption rate of the blade (mean of 5.54\%) was concentrated at 60 days of leaf age $\left(x^{2}=84.433 ; p<0.001\right)$, when leaves were completely expanded and young (Figure 2D). The consumption rate was significantly lower (1.93\%) during the expansion of young leaves (up to 30 days) and also for mature leaves, with no more than $1.50 \%$ of a mature leaf blade being consumed. From 180 days on, the percentage of leaf blade consumption was one third of the value recorded in the previous month, remaining low during the following three months. No additional herbivory was observed after 270 days (July 2015). Monthly leaf blade consumption showed positive and strong correlation with monthly damaged leaves ( $r s=0.970 ; p<0.001$ ) and temperature ( $r s=0.669 ; \mathrm{p}=0.017)$.

Precipitation was continuous throughout the period. The minimum accumulated precipitation occurred in August 2015 (149.4 mm) and the highest value was recorded in July 2015 (489.4 mm). Accumulated precipitation during the 12 months of the study was $3,273 \mathrm{~mm}$ (Figure 1 ). Both percentages of monthly leaf consumption and of damaged leaves did not correlate with precipitation ( $\mathrm{rs}=-0.021$; $\mathrm{p}=0.948$ and $\mathrm{rs}=-0.0035 ; \mathrm{p}=0.9913$, respectively).

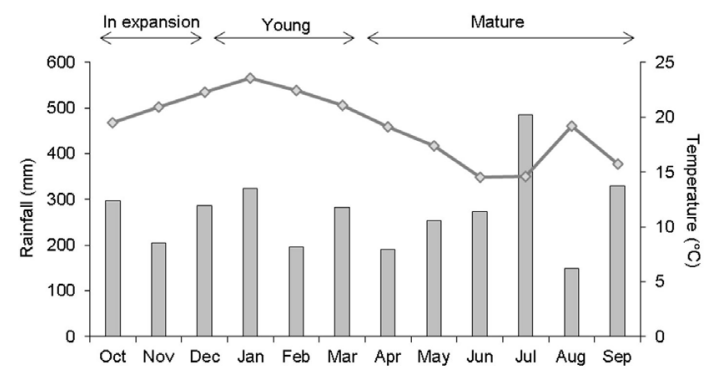

Figure 1. Accumulated monthly rainfall (columns) and monthly mean temperature (line) during monitoring of leaf expansion and herbivory on Cyathea phalerata from October 2014 to September 2015. 


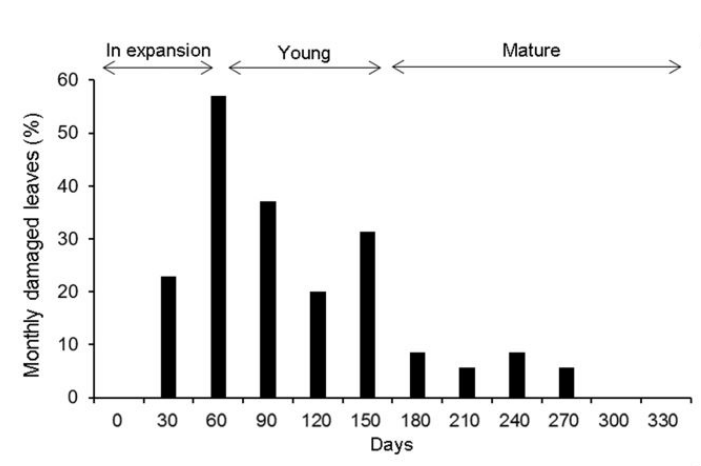

A
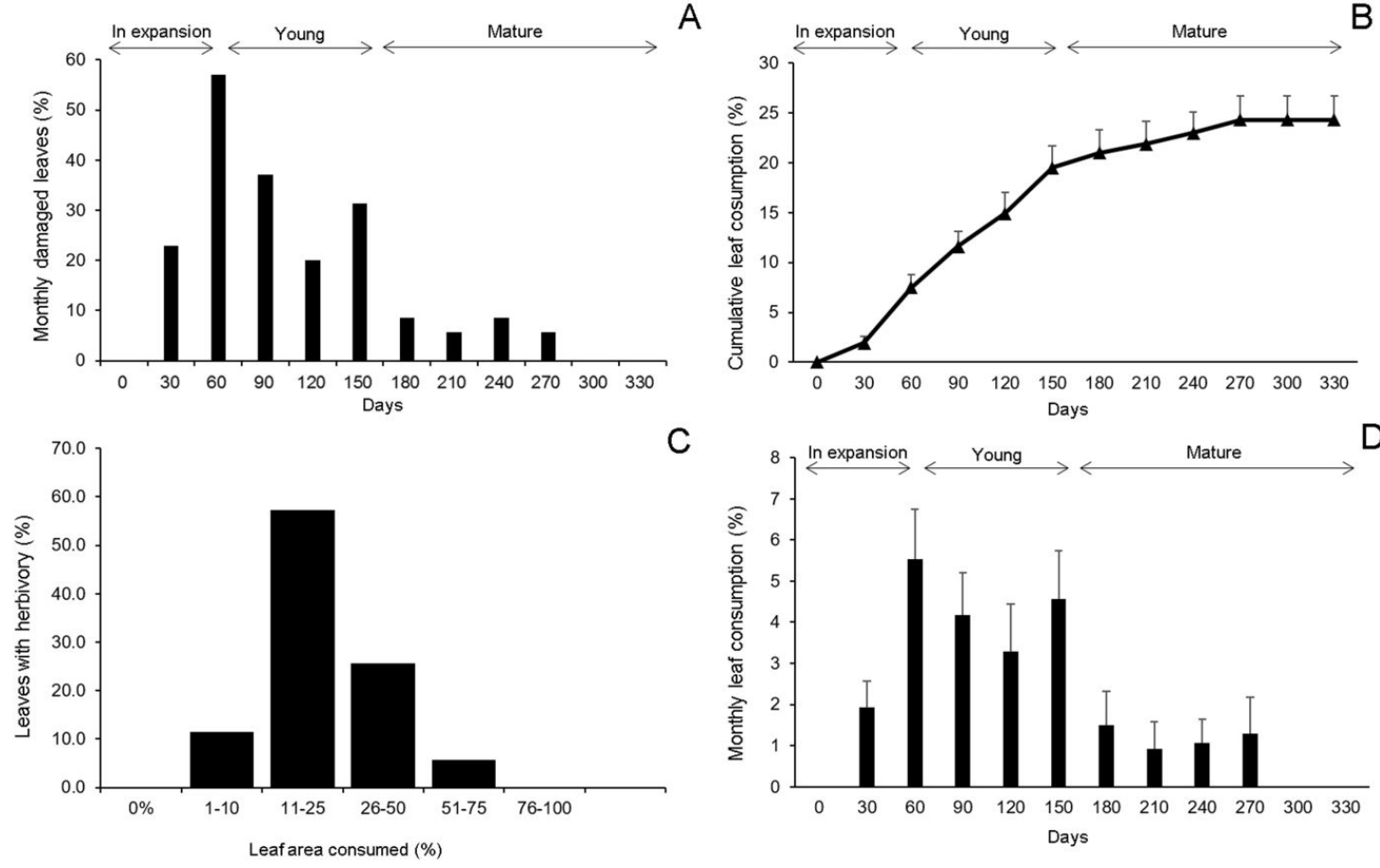

Figure 2. Monitoring of herbivory on Cyathea phalerata from October 2014 to September 2015: monthly damaged leaves (A), cumulative leaf blade consumption (B), leaves in each consumption class (C), monthly leaf blade consumption (D). Bars: standard deviation.

\section{Discussion}

No previous studies have reported on leaf expansion and quantitative leaf consumption by herbivores for C. phalerata in subtropical southern Brazil. The only plant-insect interaction reported for $C$. phalerata refers to gall production (Farias et al., 2018). Other studies have described maximum foliar expansion rates for tree ferns of Cyatheaceae Kaulf. and Dicksoniaceae M.R. Schomb. native to the study region (Table 1).Schmitt and Windisch (2012) reported higher expansion rates during the first 60 days of foliar development, as observed in the present study, which appears to be a pattern for tree ferns in the state of Rio Grande do Sul. Increased rachis length during the stage when leaves are rapidly developing is almost entirely due to the elongation of cells of the adaxial surface of the leaf, in comparison to the abaxial surface (Voeller, 1966). The magnitude of the damage caused by tissue consumption during this stage was higher because usually it interrupted the development of croziers. We emphasize that approximately $27 \%$ of the tagged croziers did not complete expansion due to the impacts of herbivory, as was also described for individuals of two populations of Alsophila setosa Kaulf., another Cyatheaceae (Schmitt and Windisch, 2005).

We did not observe the organisms responsible for consuming the leaves of $C$. phalerata, however, the damage was consistent with the action of arthropods (Patra and Bera, 2007; Del-Claro and Torezan-Silingardi, 2012; Farias et al., 2018). Insects are generally are well-adapted for feeding on ferns because they are capable of consuming leaf tissues despite of morphological and physiological
Table 1. Maximum leaf expansion rates for ferns of the state of Rio Grande do Sul, Brazil.

\begin{tabular}{lcl}
\hline \multicolumn{1}{c}{ Species } & $\begin{array}{c}\text { Maximum } \\
\text { rate }\left(\mathbf{c m}^{-1}\right)\end{array}$ & \multicolumn{1}{c}{ Reference } \\
\hline $\begin{array}{l}\text { Dicksonia sellowiana } \\
\text { Cyathea atrovirens }\end{array}$ & 3.45 & $\begin{array}{l}\text { Schmitt et al. (2009) } \\
\text { Schmitt and Windisch } \\
(2012)\end{array}$ \\
Cyathea delgadii & 6.71 & $\begin{array}{l}\text { Schmitt and Windisch } \\
(2007)\end{array}$ \\
Cyathea phalerata & 7.16 & $\begin{array}{l}\text { Present study } \\
\text { Alsophila setosa }\end{array}$ \\
Cyathea corcovadensis & 10.14 & $\begin{array}{l}\text { Schmitt and Windisch } \\
\text { (2005) }\end{array}$ \\
\hline
\end{tabular}

barriers (Balick et al., 1978; Shuter and Westoby, 1992). Although sucking insects are considered the main group of herbivores that damage ferns (Balick et al., 1978; Shuter and Westoby, 1992), we do not attribute the herbivory observed in the present study to be due to this kind of interaction since the leaves of $C$. phalerata had entire parts of their leaf blades removed. Balick et al. (1978) asserts that although damage in ferns is considerable, few arthropods can be found on the plants, which Schmitt and Windisch (2005) attributed to the nocturnal habit of the herbivores.

All 24 individuals and 48 tagged leaves monitored were damaged by herbivores at some stage of their development. This rate of herbivory is considered high according to 
data published in literature for ferns of different sizes and habits, with the most similar values being reported by Winkler et al. (2005) in a tropical mesophilic montane forest in Xalapa, Mexico. These authors found that between $60.7 \%$ and $95 \%$ of the leaves of five epiphytic fern species were damaged by herbivores, with three of the species having herbivory percentages above $90 \%$. Schmitt and Windisch (2005) reported lower values for individuals damaged, with herbivory in 28.8 and $35.4 \%$ of the $A$. setosa individuals of two populations situated in the municipalities of Morro Reuter and Sapiranga, Rio Grande do Sul, Brazil, in a seasonal semideciduous forest under the same climate as the $C$. phalerata population studied here. About $15.4 \%$ of individuals were recorded damaged in a population of Blechnum brasiliense Desv. in Novo Hamburgo, also in Rio Grande do Sul (Franz and Schmitt, 2005). Farias and Xavier (2011a) recorded a maximum of $13.63 \%$ of damaged plants for Meniscium serratum Cav., 23.52\% for Lygodium volubile Sw. and 26.31\% for Acrostichum danaeifolium Langsd. \& Fisch., in a fragment of the Atlantic Forest in the state of Paraíba, in Northeast Brazil.

Consumption rates for leaves of $C$. phalerata were high not only considering the number of damaged leaves, but also the consumption rate on each leaf blade. About 94\% of the tagged leaves had $50 \%$ or less of their area damaged, and $68.6 \%$ had $25 \%$ or less of consumed area. These values are higher than those obtained for Thelypteris turrialbae (Rosenst.) C.V. Morton, Adiantum obliquum Willd. and Polybotrya cervina (L.) Kaulf., which had 5.5, 7.3 and 9.9\% of leaf area damaged, respectively, and about 52 to $72 \%$ of the leaves with $10 \%$ of the area or less damaged (Hendrix and Marquis, 1983). The strong relationship between monthly rates of leaf consumption and damaged leaves indicates that the herbivores presented a wide distribution in individuals of $C$. phalerata, at the same time that they presented higher foliar consumption per individual.

The rate of cumulative leaf consumption in C. phalerata (24.3\%) is intermediate compared to the rates reported by Balick et al. (1978) for Blechnum varians (E. Fourn.) C. Chr. (12\%), Polystichum muricatum (L.) Fée (16\%) and Thelypteris cheilanthoides (Kunze) Proctor (38\%). Lower rates were obtained by Mehltreter and Tolome (2003) for Diplazium expansum Willd. (5.8\%), Blechnum glandulosum Kaulf. ex Link (6.1\%) and Marattia laxa Kunze (11.1\%). Despite there being no loss of individuals due to herbivory and no complete defoliation in the present study, the high percentages of consumed leaves, and the consumption rate of each leaf, may act as limiting factors for the development of $C$. phalerata. Marquis (1984) reported that even partial defoliation can have negative effects on plant development, setting back growth and reproduction and reducing competitive abilities, mainly by reducing photosynthetic capacity (Balick et al., 1978).

Leaves of $C$. phalerata were damaged during all stages of their development, as also observed by Mehltreter et al. (2006) for five epiphytic species of Polypodiaceae. Despite accumulated damage being greater when leaves are mature, as reported by other studies with ferns (Mehltreter and Tolome, 2003; Mehltreter et al., 2006; Patra and Bera, 2007), analysis of monthly herbivory data verified that herbivory is continuous beginning with leaf emission and reach its maximum in totally expanded young leaves (60 up to 150 days). The physical, chemical and biotic defenses in young leaves are not as effective at reducing herbivory as those possessed by mature leaves, which tend to be less palatable and have better defenses against herbivores (Coley et al., 1985). The lesser damage to mature leaves of $C$. phalerata can be attributed to the chartaceous texture they present in this stage (Fernandes, 2003). Leaf hardness can provide an obstacle to insect feeding due to the presence of lignified fiber bundles and cellulose (Edwards and Wratten, 1981; Varanda et al., 2005). It should be noted, however, that other factors may be influencing consumption rates, such as nutritional value, water content and chemical defenses (Nascimento et al., 2011). However, as discussed by Farias and Costa (2018), even fully expanded and turgescent fern leaves can serve as a water source for herbivores. Secondary metabolites that are usually present in mature leaves may also contribute to reducing herbivory. Investigating antioxidant activity, Hort et al. (2008) found the chemical composition of the crude extract prepared from the leaf and the fresh stem of C. phalerata to be rich in flavonoids. These compounds have different functions, such as protection against insects, fungi, viruses and bacteria; as antioxidants; and in controlling plant hormones and enzyme inhibition (Zuanazzi, 2001; Havsteen, 2002). According to Feeny (1976), secondary compounds may even render plants unpalatable, thus guaranteeing advantages for their survival (Santos, 2004). The higher monthly damage when the leaves were already expanded and also the greatest accumulated damage in mature leaves may be related to the appearance of the plant, as proposed by Feeny $(1970,1976)$ : larger plants that have their tissues and organs exposed for a longer time are more likely to be found and damaged by herbivores.

The rapid leaf expansion observed for $C$. phalerata can be considered a strategy to reduce leaf damage in young leaves by shortening the developmental period and accelerating the increase of defenses typical of mature leaves. This behavior was also observed by Aide and Londoño (1989) and Kursar and Coley (2003) in several species of angiosperms, which suggests that plants can invest more energy into rapid leaf expansion, and thus reduce the length of the developmental period when leaves are soft and vulnerable to herbivores (Feeny, 1976). Synchronous foliar production (pers. obs.) may be an additional strategy of $C$. phalerata to reduce damage from herbivory in each of the young leaves (Coley, 1983; Aide, 1988), by spreading the damage through the entire fern population and avoiding a higher rate of dead leaves.

Monthly leaf consumption and number of damaged leaves over time were strongly seasonal, occurring mainly between late spring and throughout the summer, when C. phalerata has expanding and young leaves. Patra and Bera (2007) reported important seasonality in the occurrence and abundance of herbivorous beetles on ferns in India, with the insects appearing during the hottest and rainiest season. A relationship between herbivory and precipitation was not found here for the $C$. phalerata population inserted in a subtropical forest without a defined dry season. Farias and Xavier (2011b) did not find differences in herbivory rates for Cyclosorus interruptus (Willd.) H. Itô when comparing 
damage that occurred during the wet and dry seasons, although the plants were growing in a forest subjected to seasonal rainfall in Northeast Brazil. These observations point out that the occurrence and intensity of herbivory in ferns vary greatly according to the taxa studied, the different climatic conditions, and also in response to the interaction between plant and animal. These observations suggest that herbivory in ferns may be more related to the developmental stage of the plants than to variation in abiotic factors where they are growing.

Our study revealed the relationship between the vegetative phenology of $C$. phalerata, herbivory and temperature. The rapid leaf expansion observed for C. phalerata can be a strategy to reduce damage of young leaves, minimizing the likelihood of total leaf loss and accelerating the production of defense elements. It is noteworthy that no plant loss or total defoliation was observed, even though this fern seems to be an important food resource for herbivores. The methodology used here to investigate herbivory at different stages of leaf expansion can be applied to other species of tree ferns and other families whose plants have large leaves.

\section{Acknowledgements}

This work was supported by the Research Support Foundation of the State of Rio Grande do Sul (FAPERGS) and Coordination for the Improvement of Higher Education Personnel (CAPES) by PROSUC scholarships awarded to the three first authors. JLS is supported by CNPq (PQ-308926/2017-0). We thank Feevale University for the available infrastructure, and Thábia Ottília Hofstetter Padoin, Caliel Augusto do Nascimento, Jonathan Luiz Robalski and Catiuscia Marcon for their assistance during fieldwork.

\section{References}

AGRAWAL, A.A., 2007. Macroevolution of plant defense strategies. Trends in Ecology \& Evolution, vol. 22, no. 2, pp. 103-109. http:// dx.doi.org/10.1016/j.tree.2006.10.012. PMid:17097760.

AIDE, T.M. and LONDOÑO, E.C., 1989. The effects of rapid leaf expansion on the growth and survivorship of a lepidopteran herbivore. Oikos, vol. 55, no. 1, pp. 66-70. http://dx.doi. org/10.2307/3565873.

AIDE, T.M., 1988. Herbivory as a selective agent on the timing of leaf production in a tropical understory community. Nature, vol. 336, no. 6199, pp. 574-575. http://dx.doi.org/10.1038/336574a0.

AIDE, T.M., 1991. Synchronous leaf production and herbivory in juveniles of Gustavia superba. Oecologia, vol. 88, no. 4, pp. 511514. http://dx.doi.org/10.1007/BF00317713. PMid:28312620.

AIDE, T.M., 1993. Patterns of leaf development and herbivory in a tropical understory community. Ecology, vol. 74, no. 2, pp. 455-466. http://dx.doi.org/10.2307/1939307.

BALICK, M.J., FURTH, D.G. and COOPER-DRIVER, G., 1978. Biochemical and evolutionary aspects of arthropod predation on ferns. Oecologia, vol. 35, no. 1, pp. 55-89. http://dx.doi.org/10.1007/ BF00345541. PMid:28309868.

BOWERS, M.A. and PORTER, S.D., 1981. Effect of foraging distance on water content of substrates harvested by Atta columbica
(Guerin). Ecology, vol. 62, no. 1, pp. 273-275. http://dx.doi. org/10.2307/1936686.

CALLEGARI-JACQUES, S.M., 2003. Bioestatistica: princípios e aplicações. 1. ed. Porto Alegre: Artmed, 255 p.

CHERRETT, J.M., 1972. Some factors involved in the selection of vegetable substrate by Atta cephalotes (L.) (Hymenoptera: Formicidae) in tropical rain forest. Journal of Animal Ecology, vol. 41, no. 3, pp. 647-660. http://dx.doi.org/10.2307/3200.

COLEY, P.D. and AIDE, T.M., 1991. A comparison of herbivory and plant defenses in temperate and tropical broad-leaved forests. In: P.W. PRICE, T.M. LEWINSOHN, W.W. BENSON and G.W. FERNANDES, eds. Plant-animal interactions: evolution ecology in tropical and temperate regions. New York: John Wiley and Sons, pp. 25-49.

COLEY, P.D. and BARONE, J.A., 1996. Herbivory and plant defenses in tropical forests. Annual Review of Ecology and Systematics, vol. 27, no. 1, pp. 305-335. http://dx.doi.org/10.1146/annurev. ecolsys.27.1.305.

COLEY, P.D., 1983. Herbivory and defensive characteristics of tree species in lowland tropical forest. Ecological Monographs, vol. 53, no. 2, pp. 209-233. http://dx.doi.org/10.2307/1942495.

COLEY, P.D., BRYANT, J.P. and CHAPIN III, F.S., 1985. Resource availability and plant anti-herbivore defense. Science, vol. 230, no. 4728, pp. 895-899. http://dx.doi.org/10.1126/ science.230.4728.895. PMid:17739203.

CRAWLEY, M.J., 1983. Herbivory: the dynamics of animal-plant interactions. Oxford: Blackwell Scientific Publications, 437 p.

CRAWLEY, M.J., 1989. Insect herbivores and plant population dynamics. Annual Review of Entomology, vol. 34, no. 1, pp. 531564. http://dx.doi.org/10.1146/annurev.en.34.010189.002531.

DEL-CLARO, K. and TOREZAN-SILINGARDI, H.M., 2012. Ecologia das interações plantas animais. Rio de Janeiro: Technical Books, 336 p.

EDWARDS, P.J. and WRATTEN, S.D., 1981. Ecologia das interações entre insetos e plantas. São Paulo: EPU, 78 p.

FARIAS, R.P. and COSTA, L.E.N., 2018. Selective fern herbivory by leaf-cutter ants of Atta cephalotes (L.) in Brazil. Brazilian Journal of Botany, vol. 41, no. 4, pp. 923-929. http://dx.doi.org/10.1007/ s40415-018-0499-z.

FARIAS, R.P. and XAVIER, S.R.S., 2011a. Fenologia e sobrevivência de três populações de samambaias em remanescente de Floresta Atlântica Nordestina, Paraíba, Brasil. Biotemas, vol. 24, no. 2, pp. 13-20.

FARIAS, R.P. and XAVIER, S.R.S., 2011b. Aspectos fenológicos de Thelypteris interrupta (Willd.) K. Iwats. (Thelypteridaceae) na Floresta Atlântica Nordestina, Paraíba, Brasil. Biotemas, vol. 24, no. 2, pp. 91-96. http://dx.doi.org/10.5007/2175-7925.

FARIAS, R.P., ARRUDA, C.P., SANTIAGO, A.C.P., ALMEIDA-CORTEZ, J.S., CARVALHO-FERNANDES, S.P., COSTA, L.E.N., BARROS, I.C.L. and MEHLTRETER, K., 2018. First record of galls in the tree fern Cyathea phalerata (Cyatheaceae) from a Tropical Rainforest in Brazil. Brazilian Journal of Biology = Revista Brasileira de Biologia, vol. 78, no. 4, pp. 799-801. http://dx.doi.org/10.1590/15196984.174674. PMid:29319755.

FEENY, P., 1970. Seasonal changes in oak leaf tannins and nutrients as a cause of spring feeding by winter moth caterpillars. Ecology, vol. 51, no. 4, pp. 565-581. http://dx.doi.org/10.2307/1934037.

FEENY, P., 1976. Plant appearance and chemical defense. Recent Advances in Phytochemistry, vol. 10, pp. 1-40.

FERNANDES, G.W., 1994. Plant mechanical defenses against insect herbivory. Revista Brasileira de Entomologia, vol. 38, no. 2, pp. 421-433. 
FERNANDES, I., 2003. Taxonomia dos representantes de Cyatheaceae do Nordeste Oriental do Brasil. Pesquisas. Botânica, vol. 5, no. 3, pp. 7-53.

FRANZ, I. and SCHMITT, J.L., 2005. Blechnum brasiliense Desv. (Pteridophyta, Blechnaceae): estrutura populacional e desenvolvimento da fase esporofítica. Pesquisas, Botânica, vol. 56, pp. 173-184.

FUTUYMA, D.J. and AGRAWAL, A.A., 2009. Macroevolution and the biological diversity of plants and herbivores. Proceedings of the National Academy of Sciences of the United States of America, vol. 106, no. 43, pp. 18054-18061. http://dx.doi.org/10.1073/ pnas.0904106106. PMid:19815508.

GONZATTI, F., MACHADO, L. and WINDISCH, P.G., 2016. Distribution patterns of ferns and lycophytes in the Coastal Region of the state of Rio Grande do Sul, Brazil. Acta Botanica Brasílica, vol. 30, no. 2, pp. 239-253. http://dx.doi.org/10.1590/0102$33062016 a b b 0058$.

HANLEY, M.E., LAMONT, B.B., FAIRBANKS, M.M. and RAFFERTY, C.M., 2007. Plant structural traits and their role in antiherbivore defense. Perspectives in Plant Ecology, Evolution and Systematics, vol. 8, no. 4, pp. 157-178. http://dx.doi.org/10.1016/j. ppees.2007.01.001.

HAVSTEEN, B.H., 2002. The biochemistry and medical significance of the flavonoids. Pharmacology \& Therapeutics, vol. 96, no. 2-3, pp. 67-202. http://dx.doi.org/10.1016/S0163-7258(02)00298-X. PMid:12453566.

HENDRIX, S.D. and MARQUIS, R.J., 1983. Herbivore damage to three tropical ferns. Biotropica, vol. 15, no. 2, pp. 108-111. http:// dx.doi.org/10.2307/2387952.

HOLM, S., 1979. A simple sequentially rejective multiple test procedure. Scandinavian Journal of Statistics, vol. 6, no. 2, pp. 65-70.

HORT, M.A., DALBÓ, S., BRIGHENTE, I.M.C., PIZZOLATTI, M.G., PEDROSA, R.C. and RIBEIRO-DO-VALLE, R.M., 2008. Antioxidant and hepatoprotective effects of Cyathea phalerata Mart. (Cyatheaceae). Basic \& Clinical Pharmacology \& Toxicology, vol. 103, no. 1, pp. 17-24. http://dx.doi.org/10.1111/j.17427843.2008.00214.x. PMid:18482221.

HOWARD, J.J., 1987. Leaf cutting ant diet selection: the role of nutrients, water, and secondary chemistry. Ecology, vol. 68, no. 3, pp. 503-515. http://dx.doi.org/10.2307/1938455.

KOPTUR, S., PALACIOS-RIOS, M., DÍAZ-CASTELAZO, C., MACKAY, W.P. and RICO-GRAY, V., 2013. Nectar secretion on fern fronds associated with lower levels of herbivore damage: field experiments with a widespread epiphyte of Mexican cloud forest remnants. Annals of Botany, vol. 111, no. 6, pp. 1277 1283. http://dx.doi.org/10.1093/aob/mct063. PMid:23609022.

KURSAR, T.A. and COLEY, P.D., 2003. Convergence in defense syndromes of young leaves in tropical rainforests. Biochemical Systematics and Ecology, vol. 31, no. 8, pp. 929-949. http:// dx.doi.org/10.1016/S0305-1978(03)00087-5.

LEHNERT, M., 2006. The Cyatheaceae and Dicksoniaceae (Pteridophyta) of Bolivia. Brittonia, vol. 58, no. 3, pp. 229244. http://dx.doi.org/10.1663/0007-196X(2006)58[229:TC ADPO]2.0.CO;2.

LOWMAN, M.D., 1982. Effects of different rates and methods of leaf area removal on rain forest seedlings of Coachwood (Ceratopetalum apetalum). Australian Journal of Botany, vol. 30, no. 3, pp. 477-483. http://dx.doi.org/10.1071/BT9820477.

LOWMAN, M.D., 1985. Insect herbivory in Australian rain forests - is it higher than in the Neotropics? Proceedings of the Ecological Society of Australia, vol. 14, pp. 109-119.
MALLMANN, I.T., SILVA, V.L., PORT, R.K., OLIVEIRA, F.B. and SCHMITT, J.L., 2019. Spatial distribution analysis of Dicksonia sellowiana Hook. in Araucaria forest fragments with different sizes. Brazilian Journal of Biology $=$ Revista Brasileira de Biologia, vol. 79, no. 2, pp. 337-344. http://dx.doi.org/10.1590/1519-6984.186083. PMid:30133559.

MARCON, C., SILVEIRA, T., SCHMITT, J.L. and DROSTE, A., 2017. Abiotic environmental conditions for germination and development of gametophytes of Cyathea phalerata Mart. (Cyatheaceae). Acta Botanica Brasílica, vol. 31, no. 1, pp. 58-67. http://dx.doi. org/10.1590/0102-33062016abb0288.

MARQUIS, R., 1984. Leaf herbivores decrease fitness of a tropical plant. Science, vol. 226, no. 4674, pp. 537-539. http://dx.doi. org/10.1126/science.226.4674.537. PMid:17821511.

MEHLTRETER, K. and TOLOME, J. 2003. Herbivory on three tropical fern species of a Mexican cloud forest. In: S. CHANDRA and M. SRIVASTAVA, eds. Pteridology in the New Millennium. Dordrecht: Kluwer Academic Publishers, pp. 375-381. http://dx.doi. org/10.1007/978-94-017-2811-9_26

MEHLTRETER, K., HÜLBER, K. and HIETZ, P., 2006. Herbivory on epiphytic ferns of a Mexican cloud forest. The Fern Gazette, vol. 17, no. 5, pp. 303-309.

MELLO, M.O. and SILVA-FILHO, M.C., 2002. Plant-insect interaction: an evolutionary arms race between two distinct defense mechanisms. Brazilian Journal of Plant Physiology, vol. 14, no. 2, pp. 71-81. http://dx.doi.org/10.1590/S167704202002000200001.

MURALI, K.S. and SUKUMAR, R., 1993. Leaf flushing phenology and herbivory in a tropical dry deciduous forest, southern India. Oecologia, vol. 94, no. 1, pp. 114-119. http://dx.doi.org/10.1007/ BF00317311. PMid:28313868.

NASCIMENTO, A.A., VIEIRA, A.F., SILVA, A.P., VILLELA, D.M. and NASCIMENTO, M.T., 2011. Herbivoria foliar de Xylopia sericea St. Hil. (Annonaceae) em sub-bosque de plantio de Eucalipto e de Mata Atlântica. Scientia Forestalis, vol. 39, no. 89, pp. 77-86.

NEUMANN, M.K., SCHNEIDER, P.H. and SCHMITT, J.L., 2014. Phenology, caudex growth and age estimation of Cyathea corcovadensis (Raddi) Domin (Cyatheaceae) in a subtropical forest in southern Brazil. Acta Botanica Brasílica, vol. 28, no. 2, pp. 274-280. http://dx.doi.org/10.1590/S0102-33062014000200014.

NEUVONEN, S. and HAUKIOJA, E., 1984. Low nutritive quality as defense against herbivores: induced responses in birch. Oecologia, vol. 63, no. 1, pp. 71-74. http://dx.doi.org/10.1007/ BF00379787. PMid:28311168.

PATRA, B. and BERA, S., 2007. Herbivore damage to ferns caused by a Chrysomelid beetle from lower gangetic plains of West Bengal, India. American Fern Journal, vol. 97, no. 1, pp. 1-29. http:// dx.doi.org/10.1640/0002-8444(2007)97[19:HDTFCB]2.0.CO;2.

PEEL, M.C., FINLAYSON, B.L. and MCMAHON, T.A., 2007. Updated world map of the Köppen-Geiger climate classification. Hydrology and Earth System Sciences, vol. 11, no. 5, pp. 16331644. http://dx.doi.org/10.5194/hess-11-1633-2007.

RIO GRANDE DO SUL, 2014 [viewed 8 November 2020]. Decreto $n^{\circ}$ 52.109, de 1 de dezembro de 2014. Declara as espécies da flora nativa ameaçadas de extinção no Estado do Rio Grande do Sul. Diário Oficial do Rio Grande do Sul, Porto Alegre, 1 dez. Ano LXXII, no. 233, pp. 2-11.

SANTOS, R.I., 2004. Metabolismo básico e origem dos metabólitos secundários. In: C.M.O. SIMÕES, E.P. SCHENKEL, G. GOSMANN, J.C.P. MELLO, L.A. MENTZ and P.R. PETROVICK, eds. Farmacognosia: da planta ao medicamento. Porto Alegre/Florianópolis: UFRGS/ UFSC, pp. 403-434. 
SCHMITT, J.L. and WINDISCH, P.G., 2005. Aspectos ecológicos de Alsophila setosa Kaulf. (Cyatheaceae, Pteridophyta) no Rio Grande do Sul, Brasil. Acta Botanica Brasílica, vol. 19, no. 4, pp. 861-867. http://dx.doi.org/10.1590/S0102-33062005000400021.

SCHMITT, J.L. and WINDISCH, P.G., 2007. Estrutura populacional e desenvolvimento da fase esporofitica de Cyathea delgadii Sternb. (Cyatheaceae, Monilophyta) no sul do Brasil. Acta Botanica Brasílica, vol. 21, no. 3, pp. 731-740. http://dx.doi.org/10.1590/ S0102-33062007000300019.

SCHMITT, J.L. and WINDISCH, P.G., 2010. Biodiversity and spatial distribution of epiphytic ferns on Alsophila setosa Kaulf. (Cyatheaceae) caudices in Rio Grande do Sul, Brazil. Brazilian Journal of Biology = Revista Brasileira de Biologia, vol. 70, no. 3, pp. 521-528. http://dx.doi.org/10.1590/S1519-69842010000300008. PMid:20730338.

SCHMITT, J.L. and WINDISCH, P.G., 2012. Caudex growth and phenology of Cyathea atrovirens (Langsd. \& Fisch.) Domin (Cyatheaceae) in secondary forest, southern Brazil. Brazilian Journal of Biology = Revista Brasileira de Biologia, vol. 72, no. 2, pp. 397-405. http://dx.doi.org/10.1590/S1519-69842012000200023. PMid:22735150.

SCHMITT, J.L., SCHNEIDER, P.H. and WINDISCH, P.G., 2009. Caudex growth and fenology of Dicksonia sellowiana Hook. (Dicksoniaceae) in Southern Brazil. Acta Botanica Brasílica, vol. 23, no. 1, pp. 282-291. http://dx.doi.org/10.1590/S010233062009000100030.

SHUTER, E. and WESTOBY, A., 1992. Herbivorous arthropods on bracken Pteridium aquilinum (L.) Kuhn in Australia compared with elsewhere. Australian Journal of Ecology, vol. 17, no. 3, pp. 329-339. http://dx.doi.org/10.1111/j.1442-9993.1992.tb00815.x.

SILVA, M.M., FARIAS, R.P., COSTA, L.E.N. and BARROS, I.C.L., 2018. Leaf phenological traits of the tree fern Cyathea praecincta (Cyatheaceae) in a Brazilian lowland tropical forest. Australian Journal of Botany, vol. 66, no. 8, pp. 618-627. http://dx.doi. org/10.1071/BT18084.
SOS MATA ATLÂNTICA [online], 2020 [viewed 8 November 2020]. Available from: https://www.sosma.org.br/

STRAUSS, S.Y. and AGRAWAL, A.A., 1999. The ecology and evolution of plant tolerance to herbivory. Trends in Ecology \& Evolution, vol. 14, no. 5, pp. 179-185. http://dx.doi.org/10.1016/S01695347(98)01576-6. PMid:10322530.

TUOMI, J., NIEMELÄ, P., HAUKIOJA, E., SIRÉN, S. and NEUVONEN, S., 1984. Nutrient stress: an explanation for plant anti-herbivore responses to defoliation. Oecologia, vol. 61, no. 2, pp. 208-210. http://dx.doi.org/10.1007/BF00396762. PMid:28309413.

VARANDA, E.M., BAROSELA, J.R., OKI, Y., PAIS, M.P. and CERRI, A., 2005. Defesas vegetais contra insetos folívoros. In: V.R. PIVELLO and E.M. VARANDA, eds. O cerrado Pé-de-Gigante: ecologia e conservação. São Paulo: SMA, pp. 141-152.

VOELLER, B.R., 1966. Crozier uncoiling of ferns. The Rockefeller University Review, vol. 4, pp. 14-19.

WINDISCH, P.G. and SANTIAGO, A.C.P., 2015 [viewed 8 November 2020]. Cyatheaceae. In: JARDIM BOTÂNICO DO RIO DE JANEIRO. Lista de espécies da flora do Brasil [online]. Rio de Janeiro: Jardim Botânico do Rio de Janeiro. Available from: http://floradobrasil. jbrj.gov.br/jabot/FichaPublicaTaxonUC/FichaPublicaTaxonUC. do?id=FB90894

WINKLER, M., HÜLBER, K., MEHLTRETER, K., FRANCO, J.G. and HIETZ, P., 2005. Herbivory in epiphytic bromeliads, orchids and ferns in a Mexican montane forest. Journal of Tropical Ecology, vol. 21, no. 2, pp. 147-154. http://dx.doi.org/10.1017/ S0266467404002081.

ZANGERL, A.R. and BAZZAZ, F.A., 1992. Theory and pattern in plant defense allocation. In: R.S. FRITZ and E.L. SIMMS, eds. Plant resistance to herbivores and pathogens: ecology, evolution, and genetics. Chicago: The University of Chicago Press, pp. 363-391.

ZUANAZZI, J.A.S., 2001. Flavonóides. In: C.M.O. SIMÕES, E.P. SCHENKEL, G. GOSMANN, J.C.P. MELLO, L.A. MENTZ and P.R. PETROVICK, eds. Farmacognosia: da planta ao medicamento. Porto Alegre/Florianópolis: UFRGS/UFSC, pp. 489-516. 